\title{
A methodology to generate longitudinally updated ACLF prognostication scores from electronic health record data
}

Jin Ge, MD, MBA ${ }^{1}$; Nader Najafi, $\mathrm{MD}^{2}$; Wendi Zhao, MD, MHI ${ }^{2}$; Ma Somsouk, MD, MAS ${ }^{1}$; Margaret Fang, $M D, M^{2}$; Jennifer C. Lai, MD, MBA ${ }^{1}$

${ }^{1}$ Division of Gastroenterology and Hepatology, Department of Medicine, University of California - San Francisco, San Francisco, CA

${ }^{2}$ Division of Hospital Medicine, Department of Medicine, University of California - San Francisco, San Francisco, CA

\section{Corresponding Author:}

Jennifer C. Lai, MD, MBA

513 Parnassus Avenue

UCSF Box 0538

San Francisco, CA 94143

E-mail: jennifer.lai@ucsf.edu

Fax: 415-476-0659

\section{Running Title:}

Longitudinally Updated ACLF Prognostication Scores

\section{Keywords:}

SQL, Flowsheet, NACSELD, CLIF-C, Encephalopathy

\section{Abbreviations:}

A ACLF, acute-on-chronic liver failure; $\mathrm{CDR}$, clinical data repository; $\mathrm{Cl}$, confidence interval; $\mathrm{CLIF-C-ACLF}$, European Association for the Study of Liver - Chronic Liver Failure Consortium - Acute-on-Chronic Liver Failure; CLIF-C-OF, European Association for the Study of Liver - Chronic Liver Failure Consortium Organ Failures; CVVH, continuous venovenous hemofiltration; CVVHD, continuous venovenous hemodialysis; EF-CLIF, European Foundation for the Study of Chronic Liver Failure; EHR, electronic health record; ESLD, end-stage liver disease; FiO2, oxygen fraction; FrAILT, Multi-Center Functional Assessment 
medRxiv preprint doi: https://doi.org/10.1101/2020.11.23.20237081; this version posted November $24,2020$. The copyright holder for this preprint (which was not certified by peer review) is the author/funder, who has granted medRxiv a license to display the preprint in perpetuity.

It is made available under a CC-BY-NC-ND 4.0 International license .

in Liver Transplantation Study; GCS, Glasgow Coma Score; HE, hepatic encephalopathy; ICD, International Classification of Diseases; IQR, interquartile range; INR, international normalized ratio; LFI, Liver Frailty Index; MELD, Model for End-Stage Liver Disease; MELD-Na, Model for End-Stage Liver Disease-Sodium; NACSELD, North American Consortium for the Study of End-Stage Liver Disease, NACSELD-ACLF Score, North American Consortium for the Study of End-Stage Liver Disease - Acute-onChronic Liver Failure Score; NACSELD-OF, North American Consortium for the Study of End-Stage Liver Disease - Organ Failures; OMOP, Observational Medical Outcomes Partnership; P/F Ratio, partial pressure to fraction of oxygen ratio; RRT, renal replacement therapy; SpO2, oxygen saturation; SQL, Structured Query Language; WHC, West-Haven Criteria;

\section{Financial Support:}

This study was funded by 5T32DK060414-18 (National Institute of Diabetes and Digestive and Kidney Diseases, Ge) and R01AG059183/K23AG048337 (National Institute on Aging, Lai). The funding agency played no role in the analysis of the data or the preparation of this manuscript.

\section{Word Count:}

4,770 (Including References)

\section{Author Contributions:}

Ge: Study concept and design; analysis and interpretation of data; drafting of manuscript; critical revision of the manuscript for important intellectual content; statistical analysis Najafi: Acquisition of data; interpretation of data; critical revision of the manuscript for important intellectual content

Zhao: Acquisition of data; interpretation of data

Somsouk: Interpretation of data; critical revision of the manuscript for important intellectual content Fang: Acquisition of data; interpretation of data; critical revision of the manuscript for important intellectual content

Lai: Study concept and design; analysis and interpretation of data; drafting of manuscript; critical revision of the manuscript for important intellectual content; obtained funding; study supervision

\section{Conflicts of Interest:}

The authors have no conflicts of interest to declare. 
medRxiv preprint doi: https://doi.org/10.1101/2020.11.23.20237081; this version posted November 24, 2020. The copyright holder for this preprint (which was not certified by peer review) is the author/funder, who has granted medRxiv a license to display the preprint in perpetuity.

It is made available under a CC-BY-NC-ND 4.0 International license .

\section{Writing Assistance:}

None. 
medRxiv preprint doi: https://doi.org/10.1101/2020.11.23.20237081; this version posted November $24,2020$. The copyright holder for this preprint (which was not certified by peer review) is the author/funder, who has granted medRxiv a license to display the preprint in perpetuity.

It is made available under a CC-BY-NC-ND 4.0 International license .

\begin{abstract}
:
Background and Aims:

Queries of electronic health record (EHR) data repositories allow for automated data collection. These techniques have not been utilized in hepatology due to previous inability to capture hepatic encephalopathy (HE) grades, which are inputs for acute-on-chronic liver failure (ACLF) models. Here, we describe a methodology to utilizing EHR data to calculate rolling ACLF scores.
\end{abstract}

\title{
Methods:
}

We examined 239 patient-admissions with end-stage liver disease 7/2014-6/2019. We mapped EHR flowsheet data to determine HE grades and calculated two longitudinally updated ACLF scores. We validated HE grades and ACLF diagnoses via chart review; and calculated sensitivity, specificity, and Cohen's kappa.

\section{Results:}

Of 239 patient-admissions analyzed, 37\% women, 46\% non-Hispanic White, median age 60 years, median MELD-Na at admission. Of the $239,7 \%$ were diagnosed with NACSELD-ACLF at admission, $27 \%$ during the hospitalization, and $9 \%$ at discharge. Forty percent diagnosed with CLIF-C-ACLF at admission, $51 \%$ during the hospitalization, and $34 \%$ at discharge.

From chart review of 51 admissions, we found sensitivities and specificities for any HE (grades 14) were $92-97 \%$ and $76-95 \%$, respectively; for severe HE (grades $3-4$ ) were $100 \%$ and $78-98 \%$, respectively. Cohen's kappa between flowsheet and chart review HE grades ranged 0.55-0.72. Sensitivities and specificities for NACSELD-ACLF diagnoses were $75-100 \%$ and $96-100 \%$, respectively; for CLIF-C-ACLF diagnoses were $91-100 \%$ and $96-100 \%$, respectively. We generated approximately 28 unique ACLF scores per patient per admission-day. 
medRxiv preprint doi: https://doi.org/10.1101/2020.11.23.20237081; this version posted November 24, 2020. The copyright holder for this preprint (which was not certified by peer review) is the author/funder, who has granted medRxiv a license to display the preprint in perpetuity.

It is made available under a CC-BY-NC-ND 4.0 International license .

\section{Conclusion:}

In this study, we developed an informatics-based methodology for to calculate longitudinally updated ACLF scores. This opens new analytic potentials, such big data methods to develop electronic phenotypes for ACLF patients. 
medRxiv preprint doi: https://doi.org/10.1101/2020.11.23.20237081; this version posted November 24, 2020. The copyright holder for this preprint (which was not certified by peer review) is the author/funder, who has granted medRxiv a license to display the preprint in perpetuity.

It is made available under a CC-BY-NC-ND 4.0 International license .

\section{Introduction:}

Electronic health records (EHRs) capture and generate vast amounts of granular clinical data through routine operations.(1) Structured Query Language (SQL) queries of associated clinical data repositories (CDRs) allow for automated generation of comprehensive laboratory, flowsheet, medical device, and medication administration reports for a cohort of patients.(2-4) Integration of these separate data reports have the potential to survey patients in a longitudinal fashion during inpatient admission and construct electronic phenotypes to define as subgroups of interest for further exploration.(5,6) Existing applications of SQL querying of data repositories in gastroenterology and hepatology, however, have been limited to searching International Classification of Diseases (ICD) 9/10 codes, identifying keywords in clinician documentation, and/or acquiring laboratory data.(7-9)

In hepatology research, specifically, the adoption of informatic methods described above has been hindered by inability to capture data to inform hepatic encephalopathy grades, which are often used as inputs into clinical prognostication models. Flowsheet reports, which contain structured and semi-structured entries reflecting interprofessional assessments of mentation, functional status, and physical exam findings, represent a rich source of relevant clinical information. $(3,4)$ These semistructured documentation of mentation and functional status have the potential to be mapped to describe hepatic encephalopathy, thereby enabling en-masse automated data acquisition for clinical research in hepatology.

This becomes especially relevant in the study of Acute-on-Chronic Liver Failure (ACLF), which is defined as the acute decompensation of end-stage liver disease (ESLD) with extrahepatic organ failures and high short-term mortality.(10-16) ACLF is a heterogenous and dynamic clinical syndrome with variable etiologies, triggers, and outcomes.(17) Reflecting the diversity of ACLF, several competing definitions and scoring systems currently exist, such as the North American Consortium for the Study of End-Stage Liver Disease (NACSELD diagnostic criteria and NACSELD-ACLF score)(10) and the European 
medRxiv preprint doi: https://doi.org/10.1101/2020.11.23.20237081; this version posted November $24,2020$. The copyright holder for this preprint (which was not certified by peer review) is the author/funder, who has granted medRxiv a license to display the preprint in perpetuity.

It is made available under a CC-BY-NC-ND 4.0 International license .

Association for the Study of Liver - Chronic Liver Failure Consortium (EF-CLIF diagnostic criteria and CLIFC-ACLF score).(13) Existing ACLF prognostication scores, however, are generated in a cross-sectional manner at a specific point in time - thereby remain limited in clinical utility due to inconsistent abilities to predict recovery and identify transplant candidates.(18) Moreover, the lack of consensus on an unified prognostication model implies that standard methodologies for predictive modeling may be inadequate for this disease state. Longitudinally-updated ACLF scores, therefore, may be able to improve predictive ability and better inform ACLF outcomes research as previous studies have shown score changes and trajectories have greater prognostic value.(19-22)

In this study, we describe two-step methodology to generate longitudinally updated ACLF prognostication scores (NACSELD-ACLF and CLIF-C-ACLF scores):

1. Calculate West Haven Criteria (WHC) grades of hepatic encephalopathy by mapping mentation and functional status descriptors in flowsheet reports and validating these mapped WHC grades via chart review.

2. Integrate mapped WHC grades with relationally-linked reports of laboratory value, medical device data, and medication administration reports to generate longitudinally updated ACLF prognostication scores.

\section{Materials and Methods:}

We examined all inpatient admissions in a five-year period between July 1, 2014 through June 30, 2019 for the 1,918 patients enrolled in the Multi-Center Functional Assessment in Liver Transplantation (FrAILT) Study at a single academic medical center (University of California, San Francisco Medical Center) as of October 30, 2019. The FrAILT Study is a prospective, longitudinal study of adult patients with ESLD awaiting liver transplantation evaluated in the ambulatory care setting.(23) Hospital admissions for these patients were excluded if the admission took place after liver 
medRxiv preprint doi: https://doi.org/10.1101/2020.11.23.20237081; this version posted November $24,2020$. The copyright holder for this preprint (which was not certified by peer review) is the author/funder, who has granted medRxiv a license to display the preprint in perpetuity.

It is made available under a CC-BY-NC-ND 4.0 International license .

transplantation, was for a scheduled liver transplantation within 48 hours, with total length of study $<$

24 hours, or took place prior to their enrollment in the FrAILT Study. If a patient had multiple

hospitalizations, we analyzed the hospitalization immediately after the most recent Liver Frailty Index

(LFI) assessment to isolate one admission per patient (patient-admission). Of note, all patients who are

listed for liver transplantation at our medical center are admitted to a dedicated multidisciplinary Liver

Transplant Unit jointly attended by a hepatologist and a transplant surgeon for inpatient care. A flow

diagram of the analyzed patient population from the FrAlLT Study is shown in Figure 1.

Baseline demographic and clinical data were extracted from the date of the latest outpatient

Liver Frailty Index assessment. Race/ethnicity was classified into the following categories: White, Black, Hispanic, Asian, Native American, or Other. Etiologies of liver disease were categorized as: chronic hepatitis $\mathrm{C}$, alcohol-associated, autoimmune/cholestatic, chronic hepatitis $\mathrm{B}$, and other etiologies. Patients were considered to comorbid diagnoses of hypertension, diabetes, or coronary artery disease if they were reported in the EHR. The Institutional Review Board at the University of California, San Francisco approved this study.

\section{Structured Query Lanquage Data Collection}

For this cohort of 1,918 patients and eligible admissions, we queried the EPIC (EpicCare, Epic Systems, Verona, WI) Clarity CDR hosted at the University of California, San Francisco Medical Center for the following reports containing data generated through routine care (Table 1 ). These reports were then linked relationally through two unique identifiers to each patient and admission: medical record number and contact serial number.

West Haven Criteria for Encephalopathy 
medRxiv preprint doi: https://doi.org/10.1101/2020.11.23.20237081; this version posted November $24,2020$. The copyright holder for this preprint (which was not certified by peer review) is the author/funder, who has granted medRxiv a license to display the preprint in perpetuity.

It is made available under a CC-BY-NC-ND 4.0 International license .

Hepatic encephalopathy grades were mapped based on matching of standardized/structured entries for speech, cognition, orientation level, and level of consciousness in nursing flowsheets with descriptors used for grading HE per WHC with guidance from published criteria from Hepatic Encephalopathy Scoring Algorithm (Table 2).(24-27) GCS scores were also mapped with WHC grades with GCS 15 mapping to grade 0, GCS 12-14 mapping to grade 2, GCS 4-11 mapping to grade 3, and GCS 3 mapping to grade 4.(26) If there were multiple data entries (e.g. entries for GCS, level of consciousness, and orientation) recorded at a given time or if the entries mapped to discrepant WHC grades, the maximum mapped WHC grade was used by default to maximize detection sensitivity. Structured data entries that did not fall under the above criteria, such as "Other (comment)," and unstructured data entries were excluded from mapping and analysis.

To validate the mapped WHC grades, we conducted manual chart reviews of the relevant sections (subjective findings, physical examination, and assessment and plan) of history and physical notes, progress notes, and discharge summaries of a random subset (20\%) of patient-admissions. WHC grades were assigned based on descriptors in the subjective and physical examination findings as matched to commonly accepted criteria described in practice guidelines(24), or as documented in the assessment and plan sections of the note. For example, physical examination findings of "lethargy" on chart review would be considered consistent with WHC grade 2 while findings of "arousable to voice only" or "grossly confused" would be consistent with WHC grade 3. If there were discrepancies between physical examination findings between different members of the provider team, then we utilized findings based on a hierarchical read based on the level of training. For example, the attending physician's documented examination finding would be used over that of a resident physician etc. This physician review was conducted at three timepoints during each admission: at time of initial admission, during the hospitalization (defined as maximum value acquired during the admission), at the time of discharge. 
medRxiv preprint doi: https://doi.org/10.1101/2020.11.23.20237081; this version posted November 24, 2020. The copyright holder for this preprint (which was not certified by peer review) is the author/funder, who has granted medRxiv a license to display the preprint in perpetuity.

It is made available under a CC-BY-NC-ND 4.0 International license .

\section{Determination of Oxygen Fraction (FiO2)}

Whenever available, the recorded $\mathrm{FiO} 2$ in ventilator data or vital sign flowsheets reports were utilized. If such data were not available, then we estimated FiO2 based on nasal cannula and high flow nasal cannula flow rates assuming closed mouth breathing as previously validated in respiratory care literature (Supplemental Table 1).(28-30) These recorded and estimated FiO2 values were used to calculated $\mathrm{SpO} 2 / \mathrm{FiO} 2$ and $\mathrm{P} / \mathrm{F}$ ratios when appropriate.

\section{$\underline{\text { ACLF Definitions and Prognostication Score Calculation }}$}

For each patient-admission, we used to the above data and mapped WHC grades to diagnose ACLF and calculated prognostication scores based on those published by the North American Consortium for the Study of End-Stage Liver (NACSELD-ACLF score),(10) and European Foundation for the Study of Chronic Liver Failure (CLIF-C-ACLF score).(13) The NACSELD-ACLF score (range 0-1) predicts the probability of 30-day survival in hospitalized patients (Supplemental Table 2).(10) Model for EndStage Liver Disease (MELD) and Model for End-Stage Liver Disease Sodium (MELDNa) scores were also calculated as previously described as inputs into the NACSELD-ACLF score. $(31,32)$ Similarly, the CLIF-CACLF score is a composite score (range 0 to 100 ) with a score $\geq 70$ predicting up to $100 \%$ mortality at 28 days (Supplemental Table 2).(13) We did not utilize the Asian Pacific Association for the Study of the Liver ACLF Research Consortium criteria for diagnosis due to our cohort being based in the United States and as ACLF etiologies differ significantly in patients based in the Asia-Pacific region.(18)

Using the mapped WHC grades from the methods above, we then generated automated diagnoses based on NACSELD and EF-CLIF criteria at the three timepoints specified for validation of WHC grades of HE: at time of initial admission, during the hospitalization (defined as maximum value acquired during the admission), at the time of discharge. To validate the automated ACLF diagnoses, we 
medRxiv preprint doi: https://doi.org/10.1101/2020.11.23.20237081; this version posted November $24,2020$. The copyright holder for this preprint (which was not certified by peer review) is the author/funder, who has granted medRxiv a license to display the preprint in perpetuity.

It is made available under a CC-BY-NC-ND 4.0 International license .

conducted physician chart reviews of the relevant sections (physical examination, laboratory findings, and assessment and plan) of history and physical notes, progress notes, and discharge summaries of the same random subset (20\%) of patient-admissions validated in WHC grade validation. NACSELD and EFCLIF ACLF diagnoses were confirmed based on descriptors in the physical examination findings, laboratory values, and diagnoses in the assessment and plan sections of the notes as matched to the relevant diagnostic criteria. $(10,13)$

\section{$\underline{\text { Statistical Analyses }}$}

Clinical characteristics and laboratory data for participants were summarized by medians and interquartile ranges (IQR) for continuous variables or numbers and percentages (\%) for categorical variables. Comparisons among groups were performed using chi-square and Kruskal-Wallis tests where appropriate. We calculated sensitivities and specificities of the mapped WHC grades' ability to detect any HE (WHC grades 1-4) and severe HE (WHC grades 3-4) uncovered by chart review. To rate interobserver agreement between mapped WHC grades and those acquired from chart review, we calculated Cohen's kappa coefficients and generated 95\% confidence intervals from bootstrapping with 1,000 replications.(33) Similarly, we also calculated sensitivities and specificities of the automated NACSELD-ACLF and EF-CLIF ACLF diagnoses versus manual chart diagnoses. Two-sided $p$-values $<0.05$ were considered statistically significant in all analyses. Analyses were performed using STATA statistical software, version 16.1 (StataCorp, College Station, TX, USA).

\section{Results:}

Of 1,918 patients in the FrAILT Study at the University of California, San Francisco; 480 patients (25\%) had 1,321 admissions during the five-year study period. Of these 1,321 admissions, 233 occurred after liver transplantation, 194 were admissions for the liver transplantation surgical procedure, 65 
medRxiv preprint doi: https://doi.org/10.1101/2020.11.23.20237081; this version posted November $24,2020$. The copyright holder for this preprint (which was not certified by peer review) is the author/funder, who has granted medRxiv a license to display the preprint in perpetuity.

It is made available under a CC-BY-NC-ND 4.0 International license .

lasting $\leq 24$ hours, and 318 taking place prior to enrollment in the FrAlLT Study. Of the 239 remaining patients meeting the inclusion criteria, we isolated one admission per patient for 239 patient-admissions (Figure 1).

\section{Baseline Characteristics}

Baseline characteristics of the 239 patients are presented in Table 3: 37\% were women, 46\% were non-Hispanic White, and median age at admission was 60 years (IQR 53 to 65). The most common etiologies of cirrhosis were chronic hepatitis C (31\%), alcohol-associated liver disease (24\%), nonalcoholic fatty liver disease (21\%), autoimmune/cholestatic diseases (10\%), and chronic hepatitis B (5\%). The median MELD upon admission was 21 (IQR 15 to 29) and the median MELD-Na upon admission was 25 (IQR 17 to 32 ).

\section{Validation of West Haven Criteria for Hepatic Encephalopathy}

Given that validation of WHC grades using EHR has not previously been performed, we randomly selected 51 patient-admissions (21\%) to undergo manual chart review to validate the WHC grades mapped from flowsheet data. Sensitivities and specificities (along with 95\% confidence intervals) for presence of any HE and severe HE by comparing mapped WHC grades versus chart review are presented in Table 4. The sensitivities for the presence of any HE ranged from 92-97\% while those for severe HE was $100 \%$ at the three timepoints queried (the initial time of admission, during hospitalization, and the time of discharge). Specificities for the presence of any HE ranged from 76-95\% while those for severe HE ranged from 78-98\% at the three timepoints queried. Cohen's kappa coefficient for agreement between different WHC grades were $0.55(95 \% \mathrm{Cl} 0.33-0.74)$ at time of admission, 0.64 $(95 \% \mathrm{Cl} 0.49-0.79)$ at the time of maximum value in the middle of the admission, and $0.72(95 \% \mathrm{Cl} 0.51-$ 0.90) at time of discharge. 
medRxiv preprint doi: https://doi.org/10.1101/2020.11.23.20237081; this version posted November $24,2020$. The copyright holder for this preprint (which was not certified by peer review) is the author/funder, who has granted medRxiv a license to display the preprint in perpetuity.

It is made available under a CC-BY-NC-ND 4.0 International license .

\section{$\underline{\text { ACLF Diagnoses }}$}

For the NACSELD-ACLF diagnostic criteria for ACLF, 17 patients (7\%) were diagnosed at the time of initial admission with 16 having two organ failures and one having three organ failures. The number of patients diagnosed with ACLF by the NACSELD criteria increased to 64 (27\%) during the hospitalization with 20 having two, 18 having three, and 26 having four organ failures. At the time of discharge, 21 (9\%) still had ACLF diagnoses with 7 having two, 6 having three, and 8 having four organ failures. In comparison to manual chart review of the same 51 patient-admissions selected for WHC validation, we found that the sensitivities and specificities for ACLF diagnoses under the NACSELD criteria to be $75 \%$ and $96 \%$, respectively, at the time of initial admission. The sensitivity and specificities increased to $100 \%$ and $97 \%$, respectively, during the admission; and then to $100 \%$ and $100 \%$, respectively, at the time of discharge (Table 5).

With respect to the EF-CLIF ACLF diagnostic criteria, 89 patients (40\%) wee diagnosed at the time of initial admission with 39 meeting grade one, 34 grade two, and 16 grade three criteria. The number of patients diagnosed with ACLF by the EF-CLIF criteria increased to 114 (51\%) during the hospitalization with 28 meeting grade one, 34 grade two, and 52 grade three criteria. At the time of discharge, 76 (34\%) still had ACLF diagnoses with 35 meeting grade one, 21 grade two, and 19 grade three criteria. Similarly, when we compared to manual chart review of the same 51 patient-admissions selected for WHC validation, we found that the sensitivities and specificities for ACLF diagnoses under the EF-CLIF criteria to be $91 \%$ and $96 \%$, respectively, at the time of initial admission. These figures increased to $100 \%$ and $100 \%$, respectively, during the admission and at the time of discharge (Table 5). 
medRxiv preprint doi: https://doi.org/10.1101/2020.11.23.20237081; this version posted November $24,2020$. The copyright holder for this preprint (which was not certified by peer review) is the author/funder, who has granted medRxiv a license to display the preprint in perpetuity.

It is made available under a CC-BY-NC-ND 4.0 International license .

A total of 44,639 unique data points from the 239 patient-admissions were available for ACLF prognostication score generation. This represented a median 454 data points per admission (IQR 194 to 704) and median 28 data points per admission-day (IQR 21 to 35). Using the data points generated from the relationally-linked databases, we were able to calculate approximately hourly updated NACSELDACLF and CLIF-C-ACLF scores. A representative example of one patient's hospitalization course, and the corresponding NACSELD-ACLF and CLIF-C-ACLF scores, is shown in Figure 2.

\section{Discussion:}

In this study, we validated an informatics-based method for capturing routine clinical care data from the electronic health record to calculate longitudinally updated ACLF prognostication scores in patients with ESLD hospitalized for ACLF. We extracted and mapped flowsheet data to WHC grades for HE and integrated these mapped values to more traditional data (laboratory values, device data, and medication administration records) to diagnose ACLF and calculate longitudinally-updated prognostic scores under two definitions (NACSELD-ACLF and CLIF-C-ACLF scores, Figure 2). Our method demonstrated high sensitivity in detecting any or severe HE throughout the hospitalization, and moderate sensitivity for diagnosing ACLF at admission that rapidly improved during the hospitalization.

While the techniques of using SQL queries of CDRs have been previously demonstrated,(1) existing applications have been limited.(7-9) Our method is novel in that it integrates multiple sources of EHR data: laboratory data, medication administration records, provider orders, ventilator device data, and flowsheet data. We made extensive use of flowsheets, which contain interprofessional (particularly nursing) assessments of mentation, functional status, and examination that contained structured data entries that mapped to WHC grades based on previously validated instruments. Flowsheet data comprise $1 / 3$ of all recorded data in CDRs and have been historically underutilized. $(3,4)$ Indeed, the 
medRxiv preprint doi: https://doi.org/10.1101/2020.11.23.20237081; this version posted November $24,2020$. The copyright holder for this preprint (which was not certified by peer review) is the author/funder, who has granted medRxiv a license to display the preprint in perpetuity.

It is made available under a CC-BY-NC-ND 4.0 International license .

linchpins in our novel methodology were mapping of flowsheet entries to appropriate WHC grades and of supplemental oxygenation flow rates to estimated FiO2.

Validation of WHC grades generated from flowsheet data proved to have high sensitivity (92-95\% for any $\mathrm{HE}$ and $100 \%$ for severe $\mathrm{HE}$ ) versus clinicians' documentation. Of note, HE grading has historically been difficult due to subjective assessments with poor to moderate interrater reliability.(24,34-37) This appears to be the rationale behind the use of overt hepatic encephalopathy, which have has interrater reliability, for diagnosing brain failure in both NACSELD and EF-CLIF definitions.(34) Our calculations of Cohen's Kappa coefficient indicated moderate agreement between WHC grades mapped from flowsheet data and those rated by clinicians on retrospective chart review. The Kappa coefficients from our study (0.55-0.72) are within range of those previously reported for other methodologies for differentiating WHC grades.(26,38,39) While the sensitivities and specificities of our methodology for ACLF diagnosis (based on NACSELD and EF-CLIF criteria) were imperfect at the time of initial admission, they are rapidly improved to $100 \%$ as more information was generated and gathered throughout the admission.

We acknowledge the following limitations to our study. The first is that our methodology was developed at a single-center and on a specific implementation of the EPIC EHR system. Given that our patient population are largely cared for on a dedicated Liver Transplant Unit, our staff members may be more attuned to documenting mentation accurately versus other nursing units. Specific data elements recorded in flowsheets will likely differ between institutions, but interprofessional documentation reflected flowsheet elements are generally standardized by the Joint Commission and professional associations, such as the American Nursing Association. $(4,40)$ This is a major advantage of our methodology in that it utilizes existing interdisciplinary training and charting infrastructure to discern different gradations of hepatic encephalopathy. In addition, while the exact execution for this methodology will differ at another institution, the general strategy of mapping and extracting flowsheet 
medRxiv preprint doi: https://doi.org/10.1101/2020.11.23.20237081; this version posted November $24,2020$. The copyright holder for this preprint (which was not certified by peer review) is the author/funder, who has granted medRxiv a license to display the preprint in perpetuity.

It is made available under a CC-BY-NC-ND 4.0 International license .

data remains the same. In our experience, while SQL code written for our institution's CDR does not often work "out-of-the-box" against that of another institution - the differences are generally correctable and reconcilable. Reconciliation of flowsheet data elements in a multicenter setting has been previously demonstrated with regards to the creation of a pain information model.(41) In addition, the movement towards "standard" data models, such as the Observational Medical Outcomes Partnership (OMOP), will likely greatly increase portability in the future.(42)

Second, the patient population evaluated in this study was highly selected - we only considered patients with ESLD who were enrolled in the FrAILT Study (evaluated for transplantation). This high degree of selection, however, was by design to validate our methodology in a controlled cohort and raise possibilities for implementations in larger cohorts, such as all patients with ICD-9/10 discharge diagnoses of cirrhosis. Lastly, given that the University of California, San Francisco Medical Center is a tertiary referral center, many of the admissions evaluated in our study were transferred to our medical center. Patient-admissions in our sample, thus, may not reflect the initial clinical course. Moreover, we suspect that initial delays in documentation or clinician order placement (such as entering orders for dialysis) for transfer admissions contributed to the relatively poor sensitivity of our method for diagnosis of NACSELD ACLF upon admission compared to chart review. As expected, the accuracy and precision of our methodology increased through the length of stay as more data is integrated.

Despite these limitations, this study serves as a proof of concept for a clinical informatics-based methodology to generate longitudinally updated ACLF prognostication scores, which can better reflect the dynamic clinical course of these patients. Pilot demonstration of the validity of this methodology to extract accurate data in this population opens new analytic potentials, such as the application of big data methods, that leverage the rich data from EHR platforms and CDR configurations to enhance investigation of predictors of outcomes in this dynamic population. 


\section{References:}

1. Atreja A, Achkar J-P, Jain AK, Harris CM, Lashner BA. Using technology to promote gastrointestinal outcomes research: a case for electronic health records. Am. J. Gastroenterol. 2008;103:21712178.

2. Milinovich A, Kattan MW. Extracting and utilizing electronic health data from Epic for research. Ann Transl Med. 2018;6:42.

3. Waitman LR, Warren JJ, Manos EL, Connolly DW. Expressing observations from electronic medical record flowsheets in an $\mathrm{i} 2 \mathrm{~b} 2$ based clinical data repository to support research and quality improvement. AMIA Annu. Symp. Proc. 2011;2011:1454-1463.

4. Johnson SG, Byrne MD, Christie B, Delaney CW, LaFlamme A, Park JI, et al. Modeling flowsheet data for clinical research. AMIA Jt Summits TransI Sci Proc. 2015;2015:77-81.

5. Overby CL, Pathak J, Gottesman O, Haerian K, Perotte A, Murphy S, et al. A collaborative approach to developing an electronic health record phenotyping algorithm for drug-induced liver injury. J. Am. Med. Inform. Assoc. 2013;20:e243-52.

6. Newton KM, Peissig PL, Kho AN, Bielinski SJ, Berg RL, Choudhary V, et al. Validation of electronic medical record-based phenotyping algorithms: results and lessons learned from the eMERGE network. J. Am. Med. Inform. Assoc. 2013;20:e147-54.

7. Heidemann L, Law J, Fontana RJ. A Text Searching Tool to Identify Patients with Idiosyncratic DrugInduced Liver Injury. Dig. Dis. Sci. 2017;62:615-625.

8. Rudrapatna VA, Glicksberg BS, Avila P, Harding-Theobald E, Wang C, Butte AJ. Accuracy of medical billing data against the electronic health record in the measurement of colorectal cancer screening rates. BMJ Open Qual. 2020;9.

9. Anderson AJM, Click B, Ramos-Rivers C, Babichenko D, Koutroubakis IE, Hartman DJ, et al. Development of an Inflammatory Bowel Disease Research Registry Derived from Observational Electronic Health Record Data for Comprehensive Clinical Phenotyping. Dig. Dis. Sci. 2016;61:3236-3245.

10. O'Leary JG, Reddy KR, Garcia-Tsao G, Biggins SW, Wong F, Fallon MB, et al. NACSELD acute-onchronic liver failure (NACSELD-ACLF) score predicts 30-day survival in hospitalized patients with cirrhosis. Hepatology. 2018;67:2367-2374.

11. Moreau R, Jalan R, Gines P, Pavesi M, Angeli P, Cordoba J, et al. Acute-on-chronic liver failure is a distinct syndrome that develops in patients with acute decompensation of cirrhosis. Gastroenterology. 2013;144:1426-37, 1437.e1.

12. Gustot T, Fernandez J, Garcia E, Morando F, Caraceni P, Alessandria C, et al. Clinical Course of acute-on-chronic liver failure syndrome and effects on prognosis. Hepatology. 2015;62:243-252.

13. Jalan R, Saliba F, Pavesi M, Amoros A, Moreau R, Ginès P, et al. Development and validation of a prognostic score to predict mortality in patients with acute-on-chronic liver failure. J. Hepatol. 2014;61:1038-1047. 
14. Bajaj JS, O'Leary JG, Reddy KR, Wong F, Biggins SW, Patton H, et al. Survival in infection-related acute-on-chronic liver failure is defined by extrahepatic organ failures. Hepatology. 2014;60:250256.

15. Sarin SK, Kumar A, Almeida JA, Chawla YK, Fan ST, Garg H, et al. Acute-on-chronic liver failure: consensus recommendations of the Asian Pacific Association for the study of the liver (APASL). Hepatol Int. 2009;3:269-282.

16. Sarin SK, Choudhury A, Sharma MK, Maiwall R, Al Mahtab M, Rahman S, et al. Acute-on-chronic liver failure: consensus recommendations of the Asian Pacific association for the study of the liver (APASL): an update. Hepatol Int. 2019;13:353-390.

17. Hernaez R, Solà E, Moreau R, Ginès P. Acute-on-chronic liver failure: an update. Gut. 2017;66:541553.

18. Bajaj JS, Moreau R, Kamath PS, Vargas HE, Arroyo V, Reddy KR, et al. Acute-on-Chronic Liver Failure: Getting Ready for Prime Time? Hepatology. 2018;68:1621-1632.

19. Choudhury A, Jindal A, Maiwall R, Sharma MK, Sharma BC, Pamecha V, et al. Liver failure determines the outcome in patients of acute-on-chronic liver failure (ACLF): comparison of APASL ACLF research consortium (AARC) and CLIF-SOFA models. Hepatol Int. 2017;11:461-471.

20. Rathi S, Taneja S, Duseja A, Gautam V, Chawla Y, Dhiman RK. Dynamic assessment is superior to baseline assessment in prognostication of patients with acute on chronic liver failure. J. Hepatol. 2018;68:S240-S241.

21. Mahmud N, Sundaram V, Kaplan DE, Taddei TH, Goldberg DS. Grade 1 acute on chronic liver failure is a predictor for subsequent grade 3 failure. Hepatology. 2019;

22. Sundaram V, Jalan R, Wu T, Volk ML, Asrani SK, Klein AS, et al. Factors Associated with Survival of Patients With Severe Acute-On-Chronic Liver Failure Before and After Liver Transplantation. Gastroenterology. 2019;156:1381-1391.e3.

23. Lai JC, Rahimi RS, Verna EC, Kappus MR, Dunn MA, McAdams-DeMarco M, et al. Frailty associated with waitlist mortality independent of ascites and hepatic encephalopathy in a multicenter study. Gastroenterology. 2019;156:1675-1682.

24. Vilstrup H, Amodio P, Bajaj J, Cordoba J, Ferenci P, Mullen KD, et al. Hepatic encephalopathy in chronic liver disease: 2014 Practice Guideline by the American Association for the Study of Liver Diseases and the European Association for the Study of the Liver. Hepatology. 2014;60:715-735.

25. Hassanein TI, Hilsabeck RC, Perry W. Introduction to the hepatic encephalopathy scoring algorithm (HESA). Dig. Dis. Sci. 2008;53:529-538.

26. Hassanein T, Blei AT, Perry W, Hilsabeck R, Stange J, Larsen FS, et al. Performance of the hepatic encephalopathy scoring algorithm in a clinical trial of patients with cirrhosis and severe hepatic encephalopathy. Am. J. Gastroenterol. 2009;104:1392-1400.

27. Conn HO, Leevy CM, Vlahcevic ZR, Rodgers JB, Maddrey WC, Seeff L, et al. Gastroenterology. Gastroenterology. 1943;72:573-583. 
28. Wettstein RB, Shelledy DC, Peters Jl. Delivered oxygen concentrations using low-flow and highflow nasal cannulas. Respir. Care. 2005;50:604-609.

29. Ward JJ. High-flow oxygen administration by nasal cannula for adult and perinatal patients. Respir. Care. 2013;58:98-122.

30. Chikata Y, Onodera M, Oto J, Nishimura M. FIO2 in an Adult Model Simulating High-Flow Nasal Cannula Therapy. Respir. Care. 2017;62:193-198.

31. Malinchoc M, Kamath PS, Gordon FD, Peine CJ, Rank J, ter Borg PC. A model to predict poor survival in patients undergoing transjugular intrahepatic portosystemic shunts. Hepatology. 2000;31:864-871.

32. Kim WR, Biggins SW, Kremers WK, Wiesner RH, Kamath PS, Benson JT, et al. Hyponatremia and mortality among patients on the liver-transplant waiting list. N. Engl. J. Med. 2008;359:1018-1026.

33. Reichenheim ME. Confidence intervals for the kappa statistic. The Stata Journal. 2004;4:421-428.

34. Montagnese S, Amodio P, Morgan MY. Methods for diagnosing hepatic encephalopathy in patients with cirrhosis: a multidimensional approach. Metab. Brain Dis. 2004;19:281-312.

35. Bajaj JS, Cordoba J, Mullen KD, Amodio P, Shawcross DL, Butterworth RF, et al. Review article: the design of clinical trials in hepatic encephalopathy--an International Society for Hepatic Encephalopathy and Nitrogen Metabolism (ISHEN) consensus statement. Aliment. Pharmacol. Ther. 2011;33:739-747.

36. Kircheis G, Fleig WE, Görtelmeyer R, Grafe S, Häussinger D. Assessment of low-grade hepatic encephalopathy: a critical analysis. J. Hepatol. 2007;47:642-650.

37. Hadjihambi A, Arias N, Sheikh M, Jalan R. Hepatic encephalopathy: a critical current review. Hepatol Int. 2018;12:135-147.

38. Edwin N, Peter JV, John G, Eapen CE, Graham PL. Relationship between clock and star drawing and the degree of hepatic encephalopathy. Postgrad. Med. J. 2011;87:605-611.

39. Amodio P, Campagna F, Olianas S, lannizzi P, Mapelli D, Penzo M, et al. Detection of minimal hepatic encephalopathy: normalization and optimization of the Psychometric Hepatic Encephalopathy Score. A neuropsychological and quantified EEG study. J. Hepatol. 2008;49:346353.

40. Susan McBride PhD RN-BC CPHIMS, Mari Tietze PhD RN-BC FHIMSS. Nursing Informatics for the Advanced Practice Nurse, Second Edition: Patient Safety, Quality, Outcomes, and Interprofessionalism. 2nd ed. Springer Publishing Company; 2018.

41. Westra BL, Johnson SG, Ali S, Bavuso KM, Cruz CA, Collins S, et al. Validation and Refinement of a Pain Information Model from EHR Flowsheet Data. Appl. Clin. Inform. 2018;9:185-198.

42. Stang PE, Ryan PB, Racoosin JA, Overhage JM, Hartzema AG, Reich C, et al. Advancing the science for active surveillance: rationale and design for the Observational Medical Outcomes Partnership. Ann. Intern. Med. 2010;153:600-606. 
medRxiv preprint doi: https://doi.org/10.1101/2020.11.23.20237081; this version posted November 24, 2020. The copyright holder for this preprint (which was not certified by peer review) is the author/funder, who has granted medRxiv a license to display the preprint in perpetuity.

It is made available under a CC-BY-NC-ND 4.0 International license .

\section{Table 1 - Data and Report Elements Generated from SQL Queries of Clarity CDR}

\section{Clarity CDR Report Elements}

\begin{tabular}{|c|c|}
\hline Flowsheet Report & $\begin{array}{l}\text { - Structured documentation of speech, cognition, orientation level, level of consciousness, } \\
\text { and Glasgow Coma Score (GCS) in nursing flowsheets } \\
\text { - Oxygen device, peripheral capillary oxygen saturation measurements ( } \mathrm{SpO} 2 \text { ), and blood } \\
\text { pressures by peripheral and arterial measurements in vital signs flowsheets }\end{array}$ \\
\hline $\begin{array}{l}\text { Laboratory Data } \\
\text { Report }\end{array}$ & $\begin{array}{l}\text { All laboratory (such as complete blood count, basic metabolic panel, liver function tests, } \\
\text { coagulation parameters, albumin, and others) and bacterial culture (such as urine, central } \\
\text { blood, peripheral blood, peritoneal fluid, sputum, and others) orders and results }\end{array}$ \\
\hline $\begin{array}{l}\text { Dialysis Order } \\
\text { Report }\end{array}$ & $\begin{array}{l}\text { All provider orders for hemodialysis, continuous venovenous hemofiltration (CVVH), } \\
\text { continuous venovenous hemodialysis (CVVHD), peritoneal dialysis, and ultrafiltration }\end{array}$ \\
\hline $\begin{array}{l}\text { Ventilator Data } \\
\text { Report }\end{array}$ & $\begin{array}{l}\text { Mechanical ventilation use (bilevel positive airway pressure or mechanical ventilator), } \\
\text { ventilator mode (such pressure support, assist control, and others), fraction of inspired } \\
\text { oxygen (FiO2), and partial pressure to fraction of oxygen ratio (P/F Ratio) if available }\end{array}$ \\
\hline $\begin{array}{l}\text { Vasopressor } \\
\text { Administration } \\
\text { Report }\end{array}$ & $\begin{array}{l}\text { Medication administration records and times for all administrations of epinephrine, } \\
\text { norepinephrine, phenylephrine, vasopressin, dopamine, and dobutamine }\end{array}$ \\
\hline
\end{tabular}


Table 2 - Mapping of Flowsheet Data on Four Domains of Mental Status and Glasgow Coma Score (GCS) to West Haven Criteria for Hepatic Encephalopathy*

\begin{tabular}{|c|c|c|c|c|c|}
\hline \multirow{2}{*}{$\frac{\text { West Haven Criteria }}{\text { (WHC) }(24,26,27)}$} & \multicolumn{4}{|c|}{ Flowsheet Documentation of Mentation } & \multirow{2}{*}{$\frac{\text { Glasgow Coma }}{\text { Score }}$} \\
\hline & Speech & Cognition & Orientation Level & Level of Consciousness & \\
\hline $\begin{array}{l}\text { Grade } \mathbf{0} \text { - "No encephalopathy at } \\
\text { all, no history of HE." }\end{array}$ & $\begin{array}{l}\text { - Clear } \\
\text { - Appropriate for } \\
\text { developmental } \\
\text { age } \\
\text { - Uses written } \\
\text { communication } \\
\text { - Nods/gestures } \\
\text { appropriately }\end{array}$ & $\begin{array}{l}\text { - Appropriate judgment } \\
\text { - Appropriate safety } \\
\text { awareness } \\
\text { - Appropriate attention/ } \\
\text { concentration } \\
\text { - Appropriate for } \\
\text { developmental age } \\
\text { - Follows commands } \\
\text { - No short term memory loss }\end{array}$ & $\begin{array}{l}\text { - } \text { Oriented x4 } \\
\text { - Oriented to place } \\
\text { - } \text { Oriented to time } \\
\text { - Oriented to person } \\
\text { - Oriented to } \\
\text { situation } \\
\text { - Appropriate for } \\
\text { developmental age }\end{array}$ & $\begin{array}{l}\text { - Alert } \\
\text { - Awake } \\
\text { - Responds to verbal }\end{array}$ & 15 \\
\hline $\begin{array}{l}\text { Grade } 1 \text { - "Trivial lack of } \\
\text { awareness, euphoria or anxiety, } \\
\text { shortened attention span, } \\
\text { impairment of addition or } \\
\text { subtraction, altered sleep } \\
\text { rhythm." }\end{array}$ & $\begin{array}{l}\text { - Delayed } \\
\text { responses }\end{array}$ & - Impulsive & $\begin{array}{l}\text { - Disoriented to } \\
\text { situation }\end{array}$ & & \\
\hline $\begin{array}{l}\text { Grade } 2 \text { - "Lethargy or apathy, } \\
\text { disorientation for time, obvious } \\
\text { personality change, inappropriate } \\
\text { behavior, dyspraxia, asterixis" }\end{array}$ & $\begin{array}{l}\text { - Wordfinding } \\
\text { difficulty } \\
\text { - Slurred }\end{array}$ & $\begin{array}{l}\text { - Poor safety awareness } \\
\text { - Poor judgement } \\
\text { - Poor attention/ } \\
\text { concentration } \\
\text { - Short term memory loss }\end{array}$ & $\begin{array}{l}\text { - Disoriented to } \\
\text { person } \\
\text { - Disoriented to time }\end{array}$ & - Lethargic & $12-14$ \\
\hline $\begin{array}{l}\text { Grade } 3 \text { - "Somnolence to semi } \\
\text { stupor, responsive to stimuli, } \\
\text { confused, gross disorientation, } \\
\text { bizarre behavior" }\end{array}$ & $\begin{array}{l}\text { - Incomprehensib } \\
\text { le } \\
\text { - Expressive } \\
\text { aphasia } \\
\text { - Receptive } \\
\text { aphasia }\end{array}$ & - Unable to follow commands & $\begin{array}{l}\text { - Disoriented to } \\
\text { place } \\
\text { - Disoriented x4 }\end{array}$ & $\begin{array}{l}\text { - Somnolent } \\
\text { - Responds to pain only } \\
\text { - Difficult to maintain } \\
\text { arousal } \\
\text { - Confused }\end{array}$ & $4-11$ \\
\hline Grade 4 - "Coma" & - Global aphasia & & & $\begin{array}{l}\text { - Obtunded } \\
\text { - Unresponsive }\end{array}$ & 3 \\
\hline
\end{tabular}

*This classification scheme was based on guidance from descriptors in the West Haven Criteria and criteria used in the Hepatic Encephalopathy Scoring Algorithm(24,26,27) 
medRxiv preprint doi: https://doi.org/10.1101/2020.11.23.20237081; this version posted November 24, 2020. The copyright holder for this preprint (which was not certified by peer review) is the author/funder, who has granted medRxiv a license to display the preprint in perpetuity.

It is made available under a CC-BY-NC-ND 4.0 International license .

Table 3 - Baseline Clinical and Demographic Characteristics

FrAILT Cohort ( $\mathbf{N}=\mathbf{2 3 9})$

\begin{tabular}{l|c}
\hline Age at first admission (IQR) & $60(53-65)$ \\
Female (\%) & $88(37)$ \\
Race/Ethnicity (\%) & $111(46)$ \\
White & $9(4)$ \\
Black & $81(34)$ \\
Hispanic & $23(10)$ \\
Asian & $5(2)$ \\
Native American & $10(4)$ \\
Other & \\
Etiology of Liver Disease (\%) & $75(31)$ \\
Hepatitis C & $57(24)$ \\
Alcoholic & $49(21)$ \\
Nonalcoholic fatty & $25(10)$ \\
AlH/PBC/PSC & $13(5)$ \\
Hepatitis B & $20(8)$ \\
Other etiologies & $71(30)$ \\
HCC (\%) & $112(47)$ \\
Comorbidities (\%) & $71(30)$ \\
Hypertension & $9(4)$ \\
Diabetes & $2(1)$ \\
Coronary Artery Disease & $21(15-29)$ \\
Stroke & $25(17-32)$ \\
MELD at Admission (IQR) & $17(7)$ \\
MELD-Na at Admission (IQR) & $179(76)$ \\
NACSELD-ACLF at Admission & $40(17)$ \\
NACSELD-OF 0 & $16(7)$ \\
NACSELD-OF 1 & $1(0.4)$ \\
NACSELD-OF 2 & $0(0)$ \\
NACSELD-OF 3 & $89(40)$ \\
NACSELD-OF 4 & $134(60)$ \\
CLIF-C-ACLF at Admission & $39(17)$ \\
CLIF-C-ACLF Class 0 & $34(15)$ \\
CLIF-C-ACLF Class 1 & $16(7)$ \\
CLIF-C-ACLF Class 2 & $5(2-9)$ \\
CLIF-C-ACLF Class 3 & \\
Total Length of Stay (IQR) & \\
\hline & \\
\hline
\end{tabular}


Table 4-Sensitivity and Specificity of Mapped WHC versus Chart Review

\begin{tabular}{|c|c|c|c|c|c|c|c|c|}
\hline & $\begin{array}{c}\text { True } \\
\text { Positive }\end{array}$ & $\begin{array}{c}\text { False } \\
\text { Negative }\end{array}$ & $\begin{array}{c}\text { False } \\
\text { Positive }\end{array}$ & $\begin{array}{c}\text { True } \\
\text { Negative }\end{array}$ & Sensitivity & $95 \% \mathrm{Cl}$ & Specificity & $95 \% \mathrm{Cl}$ \\
\hline Any HE (WHC 1-4) at Admission & 12 & 1 & 9 & 29 & 0.92 & $0.64-1.00$ & 0.76 & $0.60-0.89$ \\
\hline Any HE (WHC 1-4) during Hospitalization & 31 & 1 & 3 & 16 & 0.97 & $0.84-1.00$ & 0.84 & $0.60-0.97$ \\
\hline Any HE (WHC 1-4) at Discharge & 11 & 1 & 2 & 37 & 0.92 & $0.61-1.00$ & 0.95 & 0.83-0.99 \\
\hline Severe HE (WHC 3-4) at Admission & 4 & 0 & 6 & 41 & 1.00 & $0.40-1.00$ & 0.87 & $0.74-0.95$ \\
\hline Severe HE (WHC 3-4) during Hospitalization & 15 & 0 & 8 & 28 & 1.00 & $0.78-1.00$ & 0.78 & $0.61-0.90$ \\
\hline Severe HE (WHC 3-4) at Discharge & 5 & 0 & 1 & 45 & 1.00 & $0.48-1.00$ & 0.98 & $0.89-1.00$ \\
\hline
\end{tabular}

Table 5 - Sensitivity and Specificity of Calculated NACSELD-ACLF and CLIF-C-ACLF Diagnoses versus Chart Review

\begin{tabular}{|c|c|c|c|c|c|c|c|c|}
\hline & $\begin{array}{c}\text { True } \\
\text { Positive }\end{array}$ & $\begin{array}{c}\text { False } \\
\text { Negative }\end{array}$ & $\begin{array}{c}\text { False } \\
\text { Positive }\end{array}$ & $\begin{array}{c}\text { True } \\
\text { Negative }\end{array}$ & Sensitivity & $95 \% \mathrm{Cl}$ & Specificity & $95 \% \mathrm{Cl}$ \\
\hline Dx of NACSELD-ACLF at Admission & 3 & 1 & 2 & 45 & 0.75 & $0.19-0.99$ & 0.96 & $0.86-1.00$ \\
\hline Dx of NACSELD-ACLF during Hospitalization & 15 & 0 & 1 & 36 & 1.00 & $0.78-1.00$ & 0.97 & $0.86-1.00$ \\
\hline Dx of NACSELD-ACLF at Discharge & 4 & 0 & 0 & 47 & 1.00 & $0.40-1.00$ & 1.00 & $0.93-1.00$ \\
\hline Dx of CLIF-C-ACLF at Admission & 21 & 2 & 1 & 27 & 0.91 & $0.72-0.99$ & 0.96 & $0.82-1.00$ \\
\hline Dx of CLIF-C-ACLF during Hospitalization & 27 & 0 & 0 & 24 & 1.00 & $0.87-1.00$ & 1.00 & $0.86-1.00$ \\
\hline Dx of CLIF-C-ACLF at Discharge & 19 & 0 & 0 & 32 & 1.00 & $0.82-1.00$ & 1.00 & $0.89-1.00$ \\
\hline
\end{tabular}


medRxiv preprint doi: https://doi.org/10.1101/2020.11.23.20237081; this version posted November 24, 2020. The copyright holder for this preprint (which was not certified by peer review) is the author/funder, who has granted medRxiv a license to display the preprint in perpetuity. It is made available under a CC-BY-NC-ND 4.0 International license.

Figure Legend:

Figure 1 - Isolation of the 239 Patient-Admissions Analyzed in this Study

Figure 2 - Representative Sample of Calculated Longitudinal NACSELD-ACLF and CLIF-C-ACLF Scores

Supplemental Table 1 - Conversion of Nasal Cannula and High-Flow Nasal Cannula Flow Rates to

Estimated FiO2

Supplemental Table 2 - Diagnoses of ACLF based on NACSELD and EF-CLIF Criteria 
1,918 outpatients enrolled in the FrAILT Study
480 patients with 1,321

inpatient admissions
1,438 outpatients without inpatient admissions
FrAILTStudy-Multi-Center FunctionalAssessment in Liver Transplantation Study LFI-Liver Frailty Index
233 inpatient admissions after liver transplantation

194 inpatient admissions for liver transplantation procedure

65 inpatient observation stays $\leq 24$ hours

318 inpatient admissions taking place prior to patients' enrollment in FrAILT

272 inpatient admissions prior to the most recent LFI measurement
239 patients with 239 admissions isolated to the most recent LFI measurement 
Longitudinal NACSELD-ACLF and CLIF-C-ACLF Scores for One Representative Patient-Admission

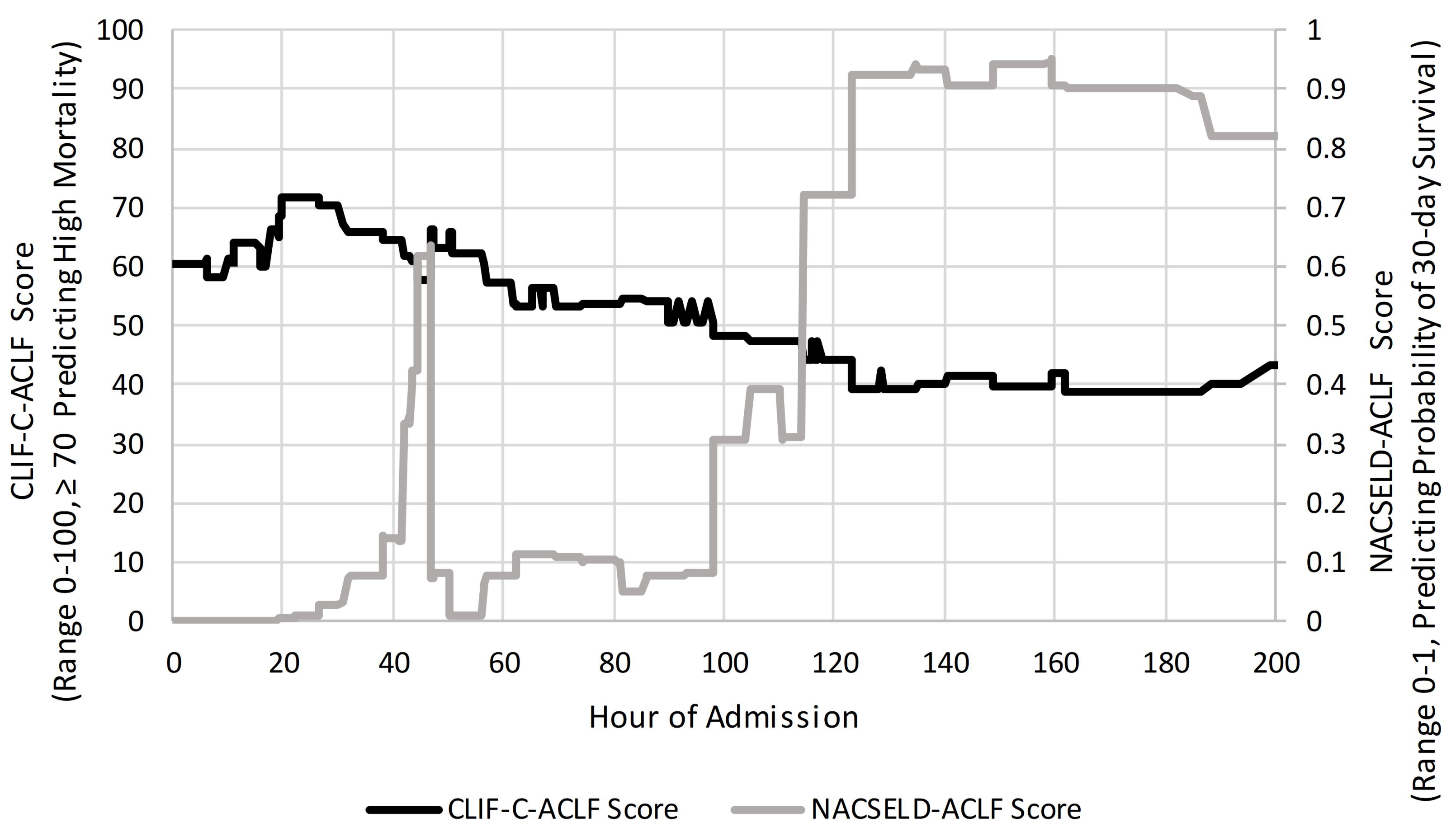

